\title{
COVID-19 Pandemic-Influenced Changes to Japanese University Student Digital Identity
}

\section{Sandra Healy \\ Kyoto Institute of Technology}

\section{Reference Data}

Healy, S. (2021). COVID-19 pandemic-influenced changes to Japanese university student digital identity. In P. Clements, R. Derrah, \& P. Ferguson (Eds.), Communities of teachers and learners. JALT. https://doi.org/10.37546/JALTPCP2020-44

This paper presents an exploratory study of Japanese university students' usage of digital space and digital identity formation in the context of the sudden move to emergency remote teaching and learning (ERTL) during the COVID-19 pandemic. An online questionnaire was administered to attempt to capture this unique historical moment, to gain a picture of the digital spaces the students typically inhabit day to day, and to document COVID-19 pandemic related changes. The questionnaire used was adapted from Lee and Kim's 2014 study on the digital identity of Korean university students, and the results were analysed using concepts from Ito et al.'s 2010 work Hanging Out, Messing Around and Geeking Out. It was found that Japanese students are immersed in a technology-rich environment, are active in friendship-driven online practices, and that the impact of the pandemic on their digital environments in connection with language learning and academic identities has been significant.

本論文は、COVID-19パンデミック時に公衆衛生対策として実施された「緊急遠隔教育・学習」(ERTL)への突然の移行環境 下における日本の大学生のデジタル空間使用とデジタル・アイデンティティ(デジタルコミュニケーション上の自己同一性) 下における日本の大学生のデジタル空間使用とデジタル・アイデンテイティ(デジタルコミュニケーショントの自己同一性)
形成を探索的に調査したものである。本研究で使用したアンケートは、韓国の大学生のデジタル・アイデンティイイ関する 形成を探索的に調査したものである。本研究で使用したアンケートは、韓国の大学生のデジタル・アイデンテイティに関する LeeとKimの2014年の論文をもとに作成され、また得られたアンケート結果は、2010年に出版されたHanging Out, Messing 環境に没入しやすく、また、オンライン演習においては友情主導で積極的に取り組むこと、そしてそれが彼らの学術的なデジ タル・アイデンティティの形成に大きな影響を与えていることが明らかになった。 $\neg$ his paper explores how students' digital identities have been impacted by the sudden move to emergency remote teaching and learning (ERTL) implemented as a result of the COVID-19 pandemic. Due to the rise in digitalization of higher education worldwide (Bond et al., 2018), researchers have examined digital identity and the use of digital tools in both social and academic contexts, as seen, for example, in lto et al. (2010), Lee and Kim (2014), Jääskelä et al. (2017), and Kuhn (2017). This kind of research has become increasingly relevant since the emergence of COVID-19 and the subsequent move to ERTL, which brought a rapid change to the digital spaces of students worldwide. Many first-year students at the Japanese national university where this study was undertaken had limited previous experience of online learning in their formal education. The shift online also coincided with their move from high school to university, and from using online spaces for largely social purposes to using them for academic purposes. Many struggled to form an academic identity during this period of upheaval, as individual identities are connected to participation in social contexts. As these social contexts change and develop, so too, do our identities. The participants' perceptions of themselves as language learners, and how they are viewed by others, as well as their actual learning experiences, are vital to the language learning process (Dornyei, 2019). As extensions of our core identities, our digital identities are also created through our participation in online activities and communities (Boyd, 2010), and these online communities underpinned the learning context for all our 2020 participants. The move to online learning meant that these learners needed to extend their digital identities to encompass academic identities with little experience or support.

\section{Literature Review}

Media ecology is a term coined in the 1960s by Marshall McLuhan (1964). It refers to the media and technology we use daily. During the last 25 years, digital media and technology have rapidly become pervasive in our lives. What is more, huge social and cultural effects have accompanied increased digital device mobility. 
A conceptual framework designed by Ito et al. (2010) was used by Lee and Kim (2014) to develop a questionnaire exploring the digital spaces inhabited by university students in Korea. The current paper uses both studies to better understand the digital spaces of Japanese undergraduate students. Ito et al. (2010) utilize four concepts to describe how youth engage with new media: genre of participation, networked public spaces, peerbased learning, and new media literacy. They describe genre of participation as "Different ways in which kids engage with new media and how their engagement relates to social participation and identity" (2010, p. 76). Two genres of participation are defined. Friendship-driven participation refers to interactions with friends and family known to the user in a local context, while interest-driven participation describes interactions with people based on shared interests alone, involving people outside the user's known circle. These two participation genres are further separated according to user engagement level, and labelled: hanging out, messing around, and geeking out. Hanging out refers to interactions with our friends or family, usually the people we interact with daily. Messing around describes online activities: information searches, video watching, listening to music, or new software use. These are typical first steps towards the interest-based third category, geeking out. Geeking out connects us to people outside our local contexts and immerses us deeply in a particular interest group.

Other concepts explored in this study include: Networked publics, new media literacy, and peer-based learning. Networked publics are transnational online spaces where people engage in public discourse, social discussion, and political debate (Chandler \& Munday, 2016). People usually belong to several online networks, including those of school, university, or workplace. These are spaces where we generate and share social and cultural knowledge as we activate and structure our digital identities. New media literacy looks at literacy practices as a form of culture, learning, and identity. We can participate in online literacy practices in many ways: creating or editing online webpages or other online content, using specialized vocabulary found online, and creating new online genres. Peer-based learning largely takes place outside formal learning. It emerges from peer-to-peer interaction with a focus on interest-driven participation and concurrent development of social norms specific to that context. Young people may develop an identity as an "expert" online even when it may be difficult for them to achieve this status in a more formal context.

The present study adapted the Lee and Kim (2014) questionnaire to the Japanese context and sought to answer the following research questions:

RQ1. To what extent are Japanese students engaged in the new media ecology?

RQ2. Using Ito et al.s (2010) conceptual framework, what tendencies are prevalent in the digital identities of the Japanese students studied?
RQ3. How were Japanese students' identities impacted by the COVID-19 pandemic?

\section{Setting and Participants}

The participants were 326 first-year undergraduate students at a science-oriented national university in Japan. Similar to the gender ratio at many national universities in Japan (Hori, 2020), 29\% of the students were female and $71 \%$ male. The questionnaire was provided in both English and Japanese as part of a larger project and was administered in July of 2020 on Google Forms online due to COVID-19 restrictions. This may have had an impact on the participants' responses regarding the pre-COVID-19 context. Informed consent was received from all participants. Cronbach's alpha was calculated and found to be .74 showing internal reliability.

\section{New Media Ecology}

\section{Results}

Overwhelmingly, participants were found to use mobile technologies. In Table 1 we can see that $88 \%$ own one mobile phone and $10 \%$, two or more. $90 \%$ own one laptop computer and $4 \%$, two or more, with very few having desktop computers (19\%). These figures were consistent with their responses concerning their primary internet access device: $57 \%$ primarily using a laptop and $39 \%$, a smartphone.

Table 1

Ownership of Electronic Devices

\begin{tabular}{lcccc}
\hline Number of devices & 0 & 1 & \multicolumn{1}{c}{2} & 3 \\
\hline Laptop & $16(4.9 \%)$ & $294(90.2 \%)$ & $13(4 \%)$ & $3(0.9 \%)$ \\
Smartphone & $2(0.6 \%)$ & $288(88.3 \%)$ & $30(9.2 \%)$ & $6(1.8 \%)$ \\
Tablet & $219(67.2 \%)$ & $101(31 \%)$ & $5(1.5 \%)$ & $1(0.3 \%)$ \\
Desktop & $265(81.3 \%)$ & $59(18.1 \%)$ & $2(0.6)$ & $0(0 \%)$ \\
\hline
\end{tabular}

Note. $N=326$. Multiple responses possible.

Table 2 shows the age at which participants received their first smartphone and computer. Mobile phones were found to be more commonly used at an earlier age than computers $-76 \%$ of the students reported mobile phone use by age 15 , whereas only $49 \%$ 
had started using a computer by that age. There is a distinct pattern regarding computer ownership with $35.6 \%$ of students receiving a computer in elementary school, very few in junior high school, and then $37.4 \%$ receiving one between the ages of 16 to 19. Most of this group reported receiving a computer on entering university revealing low levels of computer usage throughout junior and senior high school. In contrast, the majority of students received smartphones during that period.

Table 2

Age Received First Smartphone and Computer $(N=326)$

\begin{tabular}{lcr}
\hline Age & Smartphone & Computer \\
\hline $\mathbf{1 2}$ or younger & $53(16 \%)$ & $116(35.6 \%)$ \\
$\mathbf{1 3 - 1 5}$ & $194(59.5 \%)$ & $44(13.5 \%)$ \\
$\mathbf{1 6 - 1 9}$ & $78(23.9 \%)$ & $122(37.4 \%)$ \\
$\mathbf{2 0}$ or over & $1(0.3 \%)$ & $44(13.5 \%)$ \\
\hline
\end{tabular}

As seen in Table 3, the most common SNS applications used by the participants are: Line, the most popular messaging app in Japan (99\%), Twitter (83\%), Instagram (61\%), Facebook (14\%), and Tiktok (11\%).

Table 3

Use of SNS Applications

\begin{tabular}{ll}
\hline SNS & $\%$ \\
\hline Line & 99 \\
Twitter & 83 \\
Instagram & 61 \\
Facebook & 14 \\
TikTok & 11 \\
\hline
\end{tabular}

Note. $N=326$. Multiple responses possible
Table 4 shows responses to the survey questions on preferred online activities using digital devices before and after the declaration of the COVID-19 pandemic. Questions have been consecutively renumbered in Tables 4 to 9 for ease of understanding.

Table 4

Preferred Online Activities with Digital Devices $(N=326)$

\begin{tabular}{|c|c|c|c|c|c|c|}
\hline \multirow[b]{2}{*}{ Statement } & \multicolumn{3}{|l|}{$\begin{array}{l}\text { Never } \\
(\%)\end{array}$} & \multicolumn{2}{|r|}{$\begin{array}{c}\text { Always } \\
(\%)\end{array}$} & \multirow[t]{2}{*}{$\begin{array}{c}\text { Mean } \\
(\mathrm{SD})\end{array}$} \\
\hline & 1 & 2 & 3 & 4 & 5 & \\
\hline $\begin{array}{l}\text { 1a. How often did you download/ } \\
\text { edit images before COVID-19? }\end{array}$ & 27.7 & 19.4 & 26.8 & 17.8 & 8.3 & $\begin{array}{c}2.60 \\
(1.28)\end{array}$ \\
\hline $\begin{array}{l}\text { 1b. How often do you download/edit } \\
\text { images now? }\end{array}$ & 8.6 & 11.3 & 46 & 23.3 & 10.7 & $\begin{array}{c}3.16 \\
(1.05)\end{array}$ \\
\hline $\begin{array}{l}\text { 2a. How often did you download/ } \\
\text { edit videos before COVID-19? }\end{array}$ & 46.2 & 21.8 & 19.4 & 8.6 & 4 & $\begin{array}{l}2.02 \\
(1.17)\end{array}$ \\
\hline $\begin{array}{l}\text { 2b. How often do you download/edit } \\
\text { videos now? }\end{array}$ & 36.8 & 25.2 & 21.8 & 8.6 & 7.7 & $\begin{array}{l}2.26 \\
(1.25)\end{array}$ \\
\hline $\begin{array}{l}\text { 3a. How often did you exchange } \\
\text { opinions/discuss things online } \\
\text { before COVID-19? }\end{array}$ & 40.9 & 28.9 & 18.5 & 8.3 & 3.4 & $\begin{array}{c}2.04 \\
(1.11)\end{array}$ \\
\hline $\begin{array}{l}\text { 3b. How often do you exchange } \\
\text { opinions/discuss things online now? }\end{array}$ & 17.2 & 20.9 & 36.2 & 19.9 & 5.8 & $\begin{array}{c}2.76 \\
(1.13)\end{array}$ \\
\hline $\begin{array}{l}\text { 4a. How often did you write/edit } \\
\text { text messages before COVID-19? }\end{array}$ & 39.4 & 28.6 & 16.3 & 9.2 & 6.5 & $\begin{array}{l}2.15 \\
(1.22)\end{array}$ \\
\hline $\begin{array}{l}\text { 4b. How often do you write/edit text } \\
\text { messages now? }\end{array}$ & 20.2 & 19.3 & 37.4 & 13.8 & 9.2 & $\begin{array}{c}2.72 \\
(1.20)\end{array}$ \\
\hline $\begin{array}{l}\text { 5a. How often did you create } \\
\text { presentation materials before } \\
\text { COVID-19? }\end{array}$ & 33.2 & 34.2 & 24.9 & 6.8 & 0.9 & $\begin{array}{l}2.08 \\
(0.96)\end{array}$ \\
\hline $\begin{array}{l}5 \mathrm{~b} \text {. How often do you create } \\
\text { presentation materials now? }\end{array}$ & 3.1 & 10.4 & 51.5 & 28.5 & 6.4 & $\begin{array}{c}3.24 \\
(0.84)\end{array}$ \\
\hline
\end{tabular}




\begin{tabular}{|c|c|c|c|c|c|c|}
\hline \multirow[b]{2}{*}{ Statement } & \multicolumn{3}{|l|}{$\begin{array}{l}\text { Never } \\
(\%)\end{array}$} & \multicolumn{2}{|r|}{$\begin{array}{c}\text { Always } \\
\text { (\%) }\end{array}$} & \multirow[t]{2}{*}{$\begin{array}{c}\text { Mean } \\
(\mathrm{SD})\end{array}$} \\
\hline & 1 & 2 & 3 & 4 & 5 & \\
\hline $\begin{array}{l}\text { 6a. How often did you research } \\
\text { academic information online before } \\
\text { COVID-19? }\end{array}$ & 46.2 & 30.2 & 17.8 & 3.7 & 2.2 & $\begin{array}{l}1.86 \\
(0.98)\end{array}$ \\
\hline $\begin{array}{l}\text { 6b. How often do you research } \\
\text { academic information online now? }\end{array}$ & 3.1 & 3.4 & 6.1 & 53.7 & 33.7 & $\begin{array}{c}4.12 \\
(0.86)\end{array}$ \\
\hline $\begin{array}{l}\text { 7a. How often did you take online } \\
\text { classes before COVID-19? }\end{array}$ & 13.2 & 3.7 & 11.1 & 36 & 36 & $\begin{array}{c}3.78 \\
(1.33)\end{array}$ \\
\hline $\begin{array}{l}\text { 7b. How often do you take online } \\
\text { classes now? }\end{array}$ & 0 & 0 & 0 & 1.8 & 98.2 & $\begin{array}{c}4.98 \\
(0.13)\end{array}$ \\
\hline $\begin{array}{l}\text { 8a. How often did you blog before } \\
\text { COVID-19? }\end{array}$ & 93.5 & 2.5 & 3.1 & 0.3 & 0.6 & $\begin{array}{c}1.12 \\
(0.51)\end{array}$ \\
\hline 8b. How often do you blog now? & 91.7 & 3.1 & 3.4 & 0.6 & 1.2 & $\begin{array}{c}1.17 \\
(0.62)\end{array}$ \\
\hline $\begin{array}{l}\text { 9a. How often did you vlog before } \\
\text { COVID-19? }\end{array}$ & 86.8 & 6.5 & 4 & 1.5 & 1.2 & $\begin{array}{c}1.24 \\
(0.70)\end{array}$ \\
\hline 9b. How often do you vlog now? & 84 & 5.2 & 6.1 & 2.8 & 1.8 & $\begin{array}{l}1.33 \\
(0.85)\end{array}$ \\
\hline
\end{tabular}

As we can see, the most significant changes in students' online activities relate to academic work. Because all students were engaged in online classes, the related activities of searching for academic information and the creation of presentation materials increased substantially. Additionally, the participants reported low levels of online academic activity before the COVID-19 pandemic. This echoes findings by Takashiro (2018) showing that it is uncommon for schools in Japan to use technology outside of information technology (IT) classes. However, other activities online show little change pre- and post-COVID-19. Few students engaged in new media literacy related practices such as creating online content in the form of blogs (.9\% pre-COVID- 19 to $1.8 \%$ postCOVID-19) or vlogs (2.7\% pre-COVID-19 to $4.6 \%$ post-COVID-19). The participants also reported low levels of downloading/editing videos. This increased slightly from $10.6 \%$ to
$16.3 \%$. More students reported downloading/editing images which rose from $26.1 \%$ to $34.1 \%$. There is some evidence of a growth in participation in networked publics, with participants reporting an increase in exchanging opinions and discussing things online increasing from $11.7 \%$ to $25.7 \%$ post-COVID- 19 .

In short, we can see that Japanese students live in a technologically rich environment with a wealth of digital devices providing digital access and a consistent connective infrastructure. However, it seems that while SNS plays a large role enabling communication with their peers, students do not actively create online content or practice new media literacy. They are primarily consumers rather than producers preferring multimedia-based messages to text-based ones.

\section{New Media Engagement: Genre of Participation}

Japanese students showed similar tendencies to the Korean students in Lee and Kim's (2014) study. The results showed that Japanese students' main online activities are for friendship-driven purposes to maintain and strengthen relationships with their local friends, friends they have already met through family, school, or in their physical community. A lack of communication with people outside their local sphere is evidence of limited interest-driven usage. The participants reported low levels of interaction with people they had not met in person $-50 \%$ of the students had " 10 or fewer" such friends.

In terms of media engagement commitment levels, according to Ito et al.'s (2010) descriptors: hanging out, messing around, and geeking out; we can see from Table 5 that Japanese students fall squarely in the hanging out and messing around categories. They spend time enjoying communicating with their friends and family, watching videos, and listening to music. In contrast, there was little evidence of geeking out, pursuing their own interests outside their local context, or using specialist knowledge with unknown persons. Few surveyed students reported vlogging or blogging type activities.

Their reported usage patterns were similar after the initial impact of the COVID-19 pandemic, although a drop was observed in the number of students communicating with their families. As many had to return home during the lockdown period, there may have been less need to communicate with their families online. There was also an increase in gaming and satisfying their interests online which can be attributed to the increased amount of time spent at home. Creating online content also increased, moving from $3.7 \%$ to $6.8 \%$, but remained at a negligible level. 
Table 5

Engagement with New Media $(N=326)$

\begin{tabular}{|c|c|c|c|c|c|c|}
\hline & $\begin{array}{c}\text { Disagre } \\
(\%)\end{array}$ & & & & $\begin{array}{c}\text { Agree } \\
(\%)\end{array}$ & $\begin{array}{c}\text { Mean } \\
(\mathrm{SD})\end{array}$ \\
\hline Statement & 1 & 2 & 3 & 4 & 5 & \\
\hline $\begin{array}{l}\text { 10a. Main purpose of daily } \\
\text { activity BEFORE COVID-19 was } \\
\text { to communicate with my friends } \\
\text { (Hanging out) }\end{array}$ & 6.7 & 6.4 & 19 & 24.2 & 43.6 & $\begin{array}{c}3.91 \\
(1.22)\end{array}$ \\
\hline $\begin{array}{l}\text { 10b. Main purpose of daily activity } \\
\text { NOW is to communicate with my } \\
\text { friends (Hanging out) }\end{array}$ & 4.6 & 8 & 17.2 & 20.3 & 49.8 & $\begin{array}{c}4.02 \\
(1.19)\end{array}$ \\
\hline $\begin{array}{l}\text { 11a. Main purpose of daily online } \\
\text { activity BEFORE COVID-19 was } \\
\text { to communicate with my family } \\
\text { (Hanging out) }\end{array}$ & 19 & 23.9 & 24.2 & 19 & 24.2 & $\begin{array}{c}3.36 \\
(1.43)\end{array}$ \\
\hline $\begin{array}{l}\text { 11b. Main purpose of daily online } \\
\text { activity NOW is to communicate } \\
\text { with my family (Hanging out) }\end{array}$ & 24.5 & 21.2 & 21.8 & 16.6 & 16 & $\begin{array}{c}2.79 \\
(1.40)\end{array}$ \\
\hline $\begin{array}{l}\text { 12a. Main purpose of my daily } \\
\text { online activities BEFORE } \\
\text { COVID-19 was to satisfy my } \\
\text { interests (not games) (Messing } \\
\text { around) }\end{array}$ & 5.5 & 8.9 & 22.4 & 33.7 & 29.4 & $\begin{array}{c}3.72 \\
(1.14)\end{array}$ \\
\hline $\begin{array}{l}\text { 12b. Main purpose of my daily } \\
\text { online activities NOW is to satisfy } \\
\text { my interests (not games) (Messing } \\
\text { around) }\end{array}$ & 6.7 & 8 & 18.7 & 27.9 & 38.7 & $\begin{array}{c}3.84 \\
(1.21)\end{array}$ \\
\hline $\begin{array}{l}\text { 13a. Main purpose of my daily } \\
\text { online activities BEFORE } \\
\text { COVID-19 was to play online } \\
\text { games (Hanging out/Messing } \\
\text { around) }\end{array}$ & 34 & 13.8 & 15.6 & 21.5 & 15 & $\begin{array}{c}2.69 \\
(1.49)\end{array}$ \\
\hline
\end{tabular}

\begin{tabular}{lccccccc}
\hline & $\begin{array}{c}\text { Disagree } \\
\text { (\%) }\end{array}$ & & & & $\begin{array}{c}\text { Agree } \\
\text { (\%) }\end{array}$ & $\begin{array}{c}\text { Mean } \\
\text { (SD) }\end{array}$ \\
\hline & 1 & 2 & 3 & 4 & 5 & \\
\hline Statement & 33.1 & 13.2 & 13.8 & 19.6 & 20.2 & 2.80 \\
\hline $\begin{array}{l}\text { 13b. Main purpose of my daily } \\
\text { online activities NOW is to play } \\
\text { online games (Hanging out/ }\end{array}$ & & & & & & $(1.56)$ \\
$\begin{array}{l}\text { Messing around) } \\
\begin{array}{l}\text { 14a. Main purpose of my daily } \\
\text { online activities BEFORE }\end{array}\end{array}$ & 63.8 & 17.2 & 11 & 4.3 & 3.7 & 1.67 \\
$\begin{array}{l}\text { COVID-19 was to make online } \\
\text { content (Geeking out) }\end{array}$ & & & & & & $(1.07)$ \\
$\begin{array}{l}\text { 14b. Main purpose of my daily } \\
\text { online activities NOW is to make } \\
\text { online content (Geeking out) }\end{array}$ & 60.9 & 14.5 & 12.9 & 4.9 & 6.8 & 1.82 \\
\hline & & & & & & $(1.23)$ \\
\hline
\end{tabular}

New Media Engagement: Networked Public Spaces and Peer-Based Learning

If we look at the results from Table 6 concerning attitudes towards networked public cultures and peer-based learning, we can see that Japanese students, again similar to the Korean students in Lee and Kim's 2014 study, appear cautious about trusting others in public spaces. Whilst $72 \%$ of the students agree that they can get most of the information they need from their smartphones, ironically, few students believe that they can trust other net users and they are hesitant to base decisions on other online users' opinions. Only $11 \%$ agreed that the information provided by net users is trustworthy, and only $14 \%$ say they use online reviews to make decisions. A small number use other peoples' online opinions to decide their own position on social issues (13\%) and the same number say they would use new words they found on the internet. This lack of trust impacts negatively on peer-based learning and connects to the lack of geeking out activities, again echoing Lee and Kim's findings. 
Table 6

Attitudes Toward Networked Public Cultures and Peer-Based Learning ( $N=326)$

\begin{tabular}{|c|c|c|c|c|c|c|}
\hline & $\begin{array}{c}\text { Disagree } \\
(\%)\end{array}$ & & & & $\begin{array}{l}\text { Agree } \\
(\%)\end{array}$ & $\begin{array}{c}\text { Mean } \\
\text { (SD) }\end{array}$ \\
\hline Statement & 1 & 2 & 3 & 4 & 5 & \\
\hline $\begin{array}{l}\text { 15. I can get most information I } \\
\text { need with my smartphone. }\end{array}$ & 2.5 & 8 & 17.8 & 36.8 & 35 & $\begin{array}{c}3.94 \\
(1.03)\end{array}$ \\
\hline $\begin{array}{l}\text { 16. Information provided by net } \\
\text { users is trustworthy. }\end{array}$ & 13.2 & 37.4 & 38 & 9.8 & 1.5 & $\begin{array}{c}2.49 \\
(0.89)\end{array}$ \\
\hline $\begin{array}{l}\text { 17. I use online reviews to make } \\
\text { decisions. }\end{array}$ & 17.8 & 31.6 & 36.8 & 11.7 & 2.1 & $\begin{array}{c}2.49 \\
(0.98)\end{array}$ \\
\hline $\begin{array}{l}\text { 18. I use online users' opinions } \\
\text { to decide my position on certain } \\
\text { social issues. }\end{array}$ & 19.6 & 32.5 & 34.7 & 11.3 & 1.8 & $\begin{array}{c}2.43 \\
(0.99)\end{array}$ \\
\hline $\begin{array}{l}\text { 19. When I find new words on the } \\
\text { internet, l'd like to use them in } \\
\text { online communication. }\end{array}$ & 10.4 & 39.9 & 36.5 & 10.4 & 2.8 & $\begin{array}{c}2.55 \\
(0.91)\end{array}$ \\
\hline
\end{tabular}

\section{New Media Engagement: New Media Literacy}

Table 7 refers to media literacy and shows the participants' strong preference for multimodal media in contrast to traditional text-based materials. Though these students reveal that they have had extensive experience using multimodal texts outside formal education, computer use is uncommon in the Japanese junior and senior high school classroom. Until now, Japanese schools have held a deficit-oriented and protectionist view of computer usage with most simply limiting use, rather than promoting critical literacy. The IT skills students are learning outside the classroom could be harnessed and used to build language learning skills and academic identities which could then be developed in the future.
Table 7

Attitudes Toward Multimedia $(N=326)$

\begin{tabular}{|c|c|c|c|c|c|c|}
\hline & $\begin{array}{c}\text { Disagree } \\
(\%)\end{array}$ & & & & $\begin{array}{l}\text { Agree } \\
(\%)\end{array}$ & $\begin{array}{c}\text { Mean } \\
\text { (SD) }\end{array}$ \\
\hline Statement & 1 & 2 & 3 & 4 & 5 & \\
\hline $\begin{array}{l}20 \mathrm{f} \text {. Using images or video rather } \\
\text { than only text is better when } \\
\text { describing/explaining. }\end{array}$ & 1.2 & 4 & 14.5 & 38.8 & 41.5 & $\begin{array}{c}4.15 \\
(0.90)\end{array}$ \\
\hline $\begin{array}{l}20 \mathrm{~g} \text {. I prefer materials using images } \\
\text { or videos rather than text only. }\end{array}$ & 2.5 & 4.3 & 12.3 & 37.8 & 43.1 & $\begin{array}{c}4.15 \\
(0.96)\end{array}$ \\
\hline
\end{tabular}

\section{Online English Language Learning Activities and Identity}

Table 8 shows activities undertaken by students in English, on English websites. Few students use English for daily information or shopping, which is unsurprising given they live in Japan. The percentage of participants who play games in English is also very low (8\%). The most common reason participants "use English on English websites" $(58 \%)$ is to gain English practice by watching and reading the news. Internet access and computer use are strongly linked to socioeconomic status in Japan. Disadvantaged students are more likely to spend time playing online games, while advantaged students are more likely to read the news or use the internet to search for information (OECD,

2015), possibly contributing to their academic success. This seems to be borne out in this context, a reputable national university.

The current study's participants are first-year students and have only just begun to conduct academic research. This may be reflected in the low percentage of respondents (24\%) who searched for academic information in English online, an activity not required in high school as mentioned above.

Korean students showed implicit English language learning through access to English websites, which was only found to a small degree in the Japanese university students surveyed. Our respondents reported low levels of activities undertaken in English including playing games $(11 \%)$, watching TV or movies $(20 \%)$, and SNS $(18 \%)$ revealing a lack of connection with people outside of Japan. We can see that "reading/watching the news" and "studying English" were the most popular activities, both linked to explicit study purposes. 
Table 8

Activities Undertaken in English on English Websites

\begin{tabular}{lcc}
\hline Category & No. of responses & $\%$ \\
\hline News & 189 & 58 \\
Study English & 163 & 50 \\
General information & 128 & 39 \\
Music & 124 & 38 \\
Academic information & 77 & 24 \\
TV/movies & 65 & 20 \\
SNS & 59 & 18 \\
Play games & 37 & 11 \\
Daily information & 21 & 6 \\
Shopping & 21 & 6 \\
\hline
\end{tabular}

Note. $N=326$. Multiple responses possible.

Table 9 shows the activities the participants undertake to study English. The majority of students (80\%) report studying English vocabulary and grammar online, followed by watching news $(79 \%)$, using online dictionaries $(68 \%)$, reading $(63 \%)$, doing test preparation (38\%), and general listening (35\%). Active skills, such as speaking and writing are only $18 \%$ and $15 \%$ respectively, with reading E-books only accounting for $8 \%$ of responses. In short, the skills that this cohort practices online are largely passive or receptive skills, not active ones.
Table 9

Activities Used to Study English

\begin{tabular}{lcc}
\hline Category & No. of responses & $\%$ \\
\hline Vocabulary/grammar & 261 & 80 \\
News & 256 & 79 \\
Dictionary & 222 & 68 \\
Reading & 207 & 63 \\
Preparing for tests & 124 & 38 \\
Listening & 114 & 35 \\
Online lectures about English & 95 & 29 \\
Watching movies/videos & 62 & 19 \\
Speaking & 60 & 18 \\
Writing & 48 & 15 \\
Reading E-books & 25 & 8 \\
\hline
\end{tabular}

Note. $N=326$. Multiple responses possible.

\section{Discussion}

We can see clear evidence of the impact of Japanese culture on survey respondents' digital identities. Educationally, the skills used online reflect the skills practiced and valued in the Japanese education system with passive skills playing a larger role than active ones, and a heavy focus seen on vocabulary and grammar (Lee, 2011) as in Table 9. The university entrance examination washback effect (Allen, 2016), and the effects of the traditional Confucian-based education system result in exam- and teacher-centred classes. This also leads to passive, rather than active, language use. The lack of computer usage and computer education in schools compounds these problems.

The participants showed a hesitation to take part in network public cultures and a mistrust of people outside their local contexts which has an impact on the utilisation of peer-based learning, and which was exacerbated by isolation during the COVID-19 emergency. An insider-outsider dynamic is common to all societies, and in Japan this phenomenon is referred to as uchi meaning "insider or part of a group" and soto referring to "outside the group." Interestingly, similar Japanese cultural communication 
patterns can be observed through the SNS usage of this study's participants. Takahashi (2014) describes how uchi, which stems from a village mentality with its accompanying commitments and obligations, still forms an important part of Japanese communication both online and offline. The Line app allows people to belong to multiple groups and participate in a type of "village" or local communication circle. People can "create and maintain multiple uchi through their constant complex online and offline interactions in their social worlds" (p. 16), presenting and maintaining different aspects of themselves and their identities in each group. On the other hand, Twitter allows anonymity and is an escape from the burdens and pressures of the group or pair-communicative style of Line. Also, Twitter is suited to the Japanese language in that it is possible to say much more in 140 characters in Japanese, than in English. Another aspect noted by lzutsu and Izutsu (2019) is the suitability of the Japanese language for monologization, or one-way communication, in which the speaker simply states their opinion on Twitter without the intention of evoking an audience response.

From the survey responses, we can see that the emerging young adults in this study are engaging with new media in a way that reflects their cultural background and experience. The low levels of new media literacy skills, lack of integration of IT skills into the educational system, and the communicative style used in Japanese culture has led the participants to develop social identities online that embrace Ito et al's (2010) first two concepts of hanging out and messing around, but not the third, geeking out. If we compare the digital activities of the participants before and after the emergence of coronavirus, we can see a significant impact on the participants' academic identities. Prior to the pandemic, students reported low levels of computer usage at school and for homework. This drastically changed once COVID-19 emerged and the students entered university. However, there appears to have been less effect on their social identities. Aresta et al. (2013) suggest that our digital identity creation is a growth and development process and that it is important for individuals to develop a digital identity that coherently encompasses their various participatory spaces, and the participants in this study appear to be at the beginning of this journey.

\section{Conclusion}

This study attempted to identify characteristics and trends in a sample of Japanese university students' digital landscapes and the changes that the COVID-19 pandemic brought to their digital identities. Some limitations of this study include the gender balance of the participants, the high-level academic university setting, and that participant responses were self-reported after the onset of the COVID-19 pandemic.
These factors make generalization difficult. Even so, we found that Japanese students have high levels of mobile digital device ownership and engagement in friendshipdriven online practices as revealed by their high levels of SNS usage. Despite this technology-rich environment, however, participants did not take full advantage of online possibilities, and their online activities reflect their existing societal, educational and cultural patterns, rather than the creation of new patterns or spaces. The COVID-19 pandemic has brought rich opportunities for both educators and learners to expand their digital worlds, not just for consumption, but also for creation.

\section{Bio Data}

Sandra Healy is an Associate Professor at Kyoto Institute of Technology in Japan. Her research interests include using technology in English language education, and gender, language, and identity issues in language learning. <healy@kit.ac.jp>

\section{References}

Allen, D. (2016). Japanese cram schools and entrance exam washback. The Asian Journal of Applied Linguistics, 3(1), 54-67. Retrieved from https://caes.hku.hk/ajal/index.php/ajal/article/view/338

Aresta, M., Pedro, L., Santos, C., \& Moreira, A. (2013). Online identity analysis model: Analysing the construction of the self in digital environments. International Journal of Knowledge Society Research (IJKSR), 4(3), 89-102. Retrieved from https://doi.org/10.4018/ijksr.2013070108

Bond, M., Marín, V. I., Dolch, C., Bedenlier, S., \& Zawacki-Richter, O. (2018). Digital transformation in German higher education: Student and teacher perceptions and usage of digital media. International Journal of Educational Technology in Higher Education, 15(1), 48. https://doi. org/10.1186/s41239-018-0130-1

Boyd, D. (2010). Social network sites as networked publics: Affordances, dynamics, and implications. In Z. Papacharissi (Ed.), A networked self: Identity, community, and culture on social network sites (pp. 39-58). Taylor and Francis.

Chandler, D., \& Munday, R. (2016). A dictionary of social media. Oxford University Press.

Dornyei, Z. (2019). Towards a better understanding of the L2 learning experience, the Cinderella of the L2 motivational self system. Studies in Second Language Learning and Teaching, 9(1), 19-30.

Hori, R. S. (2020). Progress and problems of gender equality in Japanese academics and geosciences. Advances in Geosciences, 53, 195-203. https://doi.org/10.5194/adgeo-53-195-2020, 2020.

Ito, M., Baumer, S., Bittanti, M., Boyd, D., Cody, R., Herr-Stephenson, B., \& Pascoe, C. J. (2010). Hanging out, messing around, and geeking out. MIT Press. 
JALT2020

COMMUNITIES OF
TEACHERS \& IEARNERS

Healy: COVID-19 Pandemic-Influenced Changes to Japanese University Student Digital Identity

Izutsu, M. N., \& Izutsu, K. (2019). Why is Twitter so popular in Japan?: Linguistic devices for monologization. Internet Pragmatics, 2(2), 260-289. https://doi.org/10.1075/ip.00030.izu

Jääskelä, P., Häkkinen, P., \& Rasku-Puttonen, H. (2017). Teacher beliefs regarding learning, pedagogy, and the use of technology in higher education. Journal of Research on Technology in Education, 49(3-4), 198-211. https://doi.org/10.1080/15391523.2017.1343691

Kuhn, C. (2017). Are students ready to (re)-design their personal learning environment? The case of the e-dynamic space. Journal of New Approaches in Educational Research, 6(1), 11-19. https://doi. org/10.7821/naer.2017.1.185

Lee, J. H., \& Kim, H. (2014). An exploratory study on the digital identity formation of Korean university EFL learners. English teaching-practice and critique, 13, 149-172. Retrieved from https://files.eric.ed.gov/fulltext/EJ1050180.pdf

McLuhan, M. (1964). Understanding media: The extensions of man. McGrawHill.

OECD (2015), Students, computers and learning: Making the connection. PISA OECD Publishing. http://dx.doi.org/10.1787/9789264239555-en

Takahashi, T. (2014). Youth, social media and connectivity in Japan. In P. Seargeant \& C. Tagg (Eds.). The language of social media (pp. 186-207). Palgrave Macmillan.

Takashiro, N. (2018). Technology use and middle school students' participation in shadow education in Japan. International Psychology Bulletin, 22(4), 14-21. 